Housing Studies, Vol. 18, No. 3, 000-000, 2003

\title{
Mortgages, Minorities and Discrimination: A Bank-Specific Approach
}

\author{
SUMIT AGARWAL ${ }^{1}$ SHUMIN LI ${ }^{2}$ \& LAWRENCE MIELNICKI ${ }^{1}$ \\ ${ }^{1}$ Portfolio Risk Management, FleetBoston Financial, Providence, RI, USA \\ ${ }^{2}$ Portfolio Analytics and Research, Fannie Mae, Washington DC, USA
}

[Paper first received 20 March 2001; in final form 16 September 2002]

\begin{abstract}
The publication of the 'Fed Boston Study' drew considerable attention to the long-standing issue of discrimination of minorities in mortgage lending. Federal regulators have since stepped up their efforts to enforce greater compliance of banks with various fair-lending laws. Stengel $\mathcal{E}$ Glennon (1999), in their influential paper, offered the industry a statistical methodology that individual banks can use independently or in conjunction with traditional fair-lending enforcement procedures to self-address their compliance with the fair-lending laws. This paper reports the results of such an effort by a bank to illustrate and demonstrate that individual banks can and should conduct independent and statistically rigorous fair-lending examination for the dual purpose of self-assessment and compliance with federal fair-lending laws.
\end{abstract}

KEY WORDS: mortgage, minorities, discrimination

\section{Introduction}

As defined by US law, discrimination in lending can occur whenever the terms of a transaction are affected by personal characteristics of the participants that are not relevant to the transaction. Scholars agree that there are at least four different areas of discrimination: advertising, prescreening, application processing and product steering. However, this paper will only examine discrimination in the context of application processing. By far, the most commonly considered characteristics of discrimination in application processing are those of race and gender. In the credit market this might translate into loan approvals differing across racial groups with otherwise similar financial backgrounds. In the US, there has been an active debate on the question of whether banks discriminate against minority applicants for mortgages. For example, banks are often accused of 'redlining', that is, not granting loans for properties located in certain areas. However, discrimination in mortgage lending is not only relevant for the US market where the race of the borrower is easily identifiable. Around the world, these results can easily be understood in the context of the cultural affinity hypothesis, as proposed by Calomiris et al. (1994) and Hunter \& Walker (1996). According to this hypothesis, loan officers belonging financial situation. 
To facilitate the examination of discrimination based on the race of the borrower or the geographical location of the borrower, the Home Mortgage Disclosure Act (HMDA) of 1975 requires lenders to disclose information on the geographical location of their mortgage loans. Subsequently, in 1989 HMDA was amended to require lenders to report information on the characteristics of prospective borrowers and the disposition of their loan applications.

Furthermore, both the Fair Housing Act (FHA) of 1968 and the Equal Credit Opportunity Act (ECOA) of 1974 prohibit mortgage discrimination on the basis of a number of protected characteristics, including race. Other protected characteristics include gender, age, marital status, family status, religion, national origin, receipt of public assistance and handicap; the specific prohibitions differ slightly between the two acts. In addition, policy concerns about the viability of urban neighbourhoods have generated laws such as the Community Reinvestment Act of 1977 that imposes an affirmative obligation on federal regulatory agencies. They in turn are instructed to encourage lending institutions to help meet the credit needs of their entire community.

In view of these laws, US regulators regularly perform fair-lending examination for various lending products of all financial institutions, for example, first mortgage, second mortgage, auto loans, credit cards, small business loans, middle market loans. This study will only concentrate on first mortgage loans. The exam is conducted using several econometric techniques. One such technique would involve sorting all mortgage loan applications by product type, number of applicants, market area and applicant race. Each minority applicant is then matched to all non-minority applications filed for the same product, market, action date, number of applicants, income level and loan amount. The disposition of the minority applications (approved or denied) is then compared with the average disposition of the non-minority applicants. This comparison is averaged over all minority applications for the institution as a whole. This methodology (also knows as the matched-pair analysis), may at times result in 'false positive' results. The challenge associated with a false-positive result mainly stems from the fact that we would like to make inference about a multivariate procedure, such as loan underwriting, using a pair of observations. On the other hand, a multivariate procedure is one in which a decision is based on the weighted values of several different variables. Compared to traditional file review that relies on matched pairs, the regression analysis leads to a process that is more likely to find discrimination when it exists and less likely to find discrimination when it does not exist. For a detailed discussion on the issue of 'false positive' see Calem \& Longhofer (2000). As pointed out by a referee, there is potential for 'false negative' results as well. Hence, there is a possibility of both Type I and Type II errors. Other techniques that are employed by the regulators include a detailed loan file examination that is qualitatively similar to our own analysis. However, this study was looking for a way to give fairer treatment and conduct statistically rigorous tests on a bank's mortgage underwriting portfolio to validate compliance with the fair-lending regulations.

Since the 1996 publication of Munnell et al. (originally published as a working paper in 1992) of the Boston Federal Reserve Study ('the Boston Fed Study'), the issue of alleged mortgage discrimination by lending institutions has received widespread press, and even congressional coverage. The Boston Federal Reserve Study was undertaken in 1992 based on disaggregated 1990 Home Mortgage Disclosure Act (HMDA) data, augmented by survey data collected from Boston 
area lenders who were required to submit HMDA data. The results of this study indicated that race did play a role as lenders considered whether to deny or approve a mortgage loan application. The higher denial rate for minorities in Boston was accounted for, in large part, by their having higher loan-to-value ratios and weaker credit histories than whites.

Ever since its publication there have been several criticisms on a number of grounds. Zandi (1993) argued that the study suffered from omitted variable bias, Day \& Liebowitz (1998) claim that (i) there are so many miscoding errors in the dataset so as to make any observation drawn from it doubtful; and (ii) that a small number of highly influential observations drive the parameter estimate results on the race variable. Other contributions to the debate include Browne \& Tootell (1995); Carr \& Megbolugbe (1993); Harrison (1998); Horne (1994); Rosenblatt (1997); Ross \& Yinger (1999); Stengel \& Glennon (1999); Yezer et al. (1994). Ross \& Yinger (1999) provide a comprehensive review of the Boston Fed Study and the criticism it has received. They go on to show that the key finding of the Boston Fed Study hold up well in the face of the criticism. However, they think that individual bank models may provide better estimates of disparate treatment discrimination. Legal discussion of discrimination generally distinguishes between activities that can be classified as disparate treatment and disparate impact. Disparate treatment occurs when similarly situated persona are treated differently on the basis of race. Disparate impact occurs when an underwriting guideline disqualifies a larger share of minority than whites, unless this guideline can be justified as a business necessity that cannot reasonably be achieved as well by means which have less of a differential effect on race.

On the other hand, Buist et al. (1999) show in a compelling fashion that lenders may be able to hide disparate treatment discrimination by transforming in into disparate impact discrimination. Specifically, modelling the loan and the portfolio decision and including several new statistically significant variables, Buist et al. were able to clarify the role of the loan and lender types in determining loan disposition, but their results did not change the interpretation of the race effect. In general, they argued that even if some lenders did discriminate, they are able to devise compensating policies that eliminate differential treatment discrimination, but hide the discrimination in the form of disparate impact.

In view of the Boston Fed Study and the subsequent debate, this study will look at the issue of minority applicants, mortgage lending and discrimination using HMDA data for a large national lending institution from January to September 1999. This study was originally undertaken to prepare for an OCC fair-lending examination. Following the methodology of Stengel \& Glennon (1999), a customised model was developed, specifically taking the institution's underwriting guidelines into account. The results were presented to the OCC. The OCC subsequently approved the methodology and results. The study was also in compliance of the Comptroller's Handbook on Fair Lending (1997).

The purpose of the current study is not to evaluate the mortgage lending policy guidelines of this financial institution. In fact, there are a number of regulatory procedures and policies that are laid out by the federal regulators to evaluate the underwriting policy guidelines. Instead, this study is conducted to provide an independent and statistically rigorous look at the issue of fair lending in a context of application processing at this financial institution. The BankSpecific Approach is followed, as outlined by Stengel \& Glennon (1999). They argue that a unique model needs to be developed to test explicitly a bank's 
application of its own stated guidelines, instead of a more generic model that reflects secondary market requirements. A bank-specific approach that controls for all relevant factors used by the bank in the lending decision will measure the importance of disparate treatment discrimination by the bank. However, the importance of disparate impact discrimination could be approached by a performance study that examines racial disparities in subsequent losses from mortgage loans. Unfortunately, studies of loan performance may miss important types of disparate treatment discrimination. Berkovec et al. (1998) provide examples of performance studies in mortgage lending.

This study will follow a bank-specific approach since one of the main interests is in measuring disparate treatment discrimination in mortgage lending. Information on the detailed, bank-specific underwriting guidelines in effect during the sample period were gathered from interviews, bank mortgage lending manuals and other internal documents. This is the only other publicly available study found that has looked at the fair-lending issue following a Bank-Specific Approach.

However, Blackburn \& Vermilyea (2001) have conducted a similar study where they look at several large national banks to assess the extent of discrimination against minorities. When they looked at the minority race effect on loan denial probability on a bank specific model they did not find statistically significant estimates but when they combined their estimates across banks, they found evidence of disparate treatment discrimination.

In view of the above literature, the remainder of the paper is structured as follows: the next section will describe the data. The third section will describe the regression methodology and results, and the final section will offer concluding remarks.

\section{Data}

The data is primarily from a large national financial institution that originates loans nationally. A stratified sample of one-to-four family, conventional, nonpurchased home purchase mortgage loan applications were drawn from the HMDA Loan Application Register between January and September 1999, this time period is fairly representative of the loan underwriting process and does not in any way bias the results. Minority applications, both approvals and denials, and white denials were over sampled to overcome small sample issues. Stengel \& Glennon (1999) use a similar sampling methodology where they stratified both on race and disposition, except for white approvals to avoid small sample problems. They also point out that modelling issues raised by sample selection are important but, they believe that, "... their importance depends, at least in part, on the objective of the modeling exercise" (p. 303). Dietrich (2000) has shown that this sampling procedure can offer substantial efficiency gains over random sampling or stratification based on either race or outcome alone. However, some have argued that stratification can introduce bias to the usual estimation of the intercept and the coefficient of the race, as well as to the estimation of the standard errors for these parameters. But Maddala (1983), argues that non-proportional sampling effects the intercept "but the slope coefficients are all unbiased" when using a logit model. This study still chose to correct this bias using the technique developed by Scott \& Wild (1997). (Stengel \& Glennon (1999) do not address this point.) The adjustment is based on the 
Table 1. Sample demographics

\begin{tabular}{lcccc}
\hline Race Category & $\begin{array}{c}\text { \# of } \\
\text { Approved }\end{array}$ & $\begin{array}{c}\text { \# of } \\
\text { Declined }\end{array}$ & $\begin{array}{c}\% \text { of } \\
\text { Approved }\end{array}$ & $\begin{array}{c}\% \text { of } \\
\text { Declined }\end{array}$ \\
\hline Asian American & 44 & 32 & $58 \%$ & $42 \%$ \\
African American & 46 & 39 & $54 \%$ & $46 \%$ \\
Hispanic American & 56 & 55 & $50 \%$ & $50 \%$ \\
Total minorities & $\mathbf{1 4 6}$ & $\mathbf{1 2 6}$ & $54 \%$ & $46 \%$ \\
White & 145 & 150 & $49 \%$ & $51 \%$ \\
Total & $\mathbf{2 9 1}$ & $\mathbf{2 7 6}$ & $51 \%$ & $49 \%$ \\
\hline
\end{tabular}

racial differences in denial rates between the population and the sample. In this case, the loan probabilities for the population can be calculated from the HMDA data. Fortunately, the bias on the race coefficient does not carry over to the coefficient estimates on non-race variables, so no correction is necessary for these estimates.

There were over 100 loan files that were discarded from the original sample resulting in the final sample of 567 loan files. These included applications in which borrowers were overqualified under the guidelines of the specific loan programme and files in which the applicant rejected the bank's counter offer. These loans proved problematic because their inclusion in the regression may distort the underlying relationship between the bank's application of its policy guideline across racial groups and the disposition of the loan application. As suggested by a referee, the regression analysis treating counter offer accounts as denials was redone and the results were consistent and robust. The sample size of 567 loans is fairly representative of the entire population for the time period of the analysis.

Approximately 140 mortgages were randomly selected for minorities, non-minorities, approvals and denials respectively. Data sample demographics are presented in Table 1. The minority applicants consisted of all applications in which at least one of the applicants (either the applicant or the co-applicant was Asian American, African American, or Hispanic American). Overall sample size was consistent with samples used in bank-specific models estimated in the OCC study by Stengel \& Glennon (1999). (In their study they had 766, 729 and 522 applications from three different banks.) Furthermore, credit and collateral information was also retrieved from individual applications. Data entry and quality assurance took over six months. Experienced internal and external consultants were employed for data transfer from the underwriting documents to electronic spreadsheets. Extensive data validation and data integrity checks were performed to ensure quality control.

In all, there were 91 separate data elements collected for each loan file. They consisted of 22 HMDA data elements, 23 Loan record identification elements, 18 credit history elements, 11 collateral elements, 11 income elements and 6 asset elements. After preliminary regression analysis it was determined that the following variables will be included in the study: (i) excess back-end ratio: The ratio between debts (including principal, interest, property taxes, and insurance plus other monthly payments) to gross monthly income; (ii) excess loan-to-value ratio (LTV); (iii) credit score; (iv) previous bankruptcy indicator and previous 
charge-off indicator; (v) self-employment indicator; and (vi) insufficient cash indicator. Other variables that were modelled but were found not to be significant included Units (2-4 family) and excess front-end ratio. There were two variables that were seen in other studies but have not been included in this study due to lack of observations. They include, net worth and special banking relationships.

\section{Model Specification and Results}

The regression methodology used in this study to measure discriminatory lending behaviour is based on the following model of the mortgage loan decision:

$\operatorname{Prob}(\mathrm{y}=1 \mid \mathrm{X}, \mathrm{z})=\mathrm{b}^{\prime} \mathrm{X}+\mathrm{az}+\mathrm{e}$,

where $y=1$, if the loan application is accepted, $X$ is a set of borrower, property and financial covariates (in particular these covariates include, Excess back-end ratio, Excess LTV, Credit Score, Prior Bankruptcy Indicator, etc.) conceptually including all factors used in loan underwriting, and $z=$ an indicator variable for the presence of attribute against which lenders may discriminate; here $z=1$ if applicant is minority, $z=0$ otherwise. The variable $e$ represents an additional unobserved random error term. The parameter of interest, then, is ' $a$ ', and a negative value significantly different from zero is taken as a measure of discriminatory lender behaviour.

The following model specification will be used to test whether the value for the parameter ' $a$ ' is statistically significant from zero. For the purpose of this study there are two model specifications; Model 1, defines $z=1$ to indicate all minorities (African American, Asian American and Hispanic American). Model 2 defines $z 1=1$ to indicate African Americans and $z 1=0$ otherwise, $z 2=1$ to indicate Asian Americans and $z 2=0$ otherwise, and $z 3=1$ to indicate Hispanic Americans and $z 3=0$ otherwise. However, as discussed earlier, stratification of the data could have introduced bias to the usual estimation of the intercept and the coefficient of the race, as well as to the estimation of the standard errors for these parameters. This bias is corrected using the technique developed by Scott \& Wild (1997). The adjusted results are presented in Table 2.

The results indicate that in the above model specification parameter ' $a$ ' is statistically insignificant. Other variables that are plausible determinants of being accepted for a loan are highly significant and have the correct sign. Credit score is significant for both model specifications, so is excess LTV (loan/value), prior bankruptcy, prior charge-off, and excess back-end ratio (debt/income). This is consistent with most other studies on this topic. These statistics also show that minorities are not being discriminated during the underwriting process at this financial institution.

\section{Conclusion}

The publication of the 'Fed Boston Study' drew a considerable attention to the long-standing issue of discrimination of minorities in mortgage lending. Ever since federal regulators have stepped up their effort to enforce greater compliance of banks with various federal fair-lending laws. This paper reports the results of such an effort by a bank to illustrate and demonstrate that individual 
Table 2. Logistic regressions results (adjusted for sample stratification)

\begin{tabular}{|c|c|c|c|c|}
\hline \multirow[b]{2}{*}{ Independent variables } & \multicolumn{4}{|c|}{ Dependent variable: Accept } \\
\hline & $\begin{array}{l}\text { Model } 1 \\
\text { Estimate }\end{array}$ & $p$-value & $\begin{array}{l}\text { Model } 2 \\
\text { Estimate }\end{array}$ & $p$-value \\
\hline Intercept & $\begin{array}{l}-8.2469 \\
(-3.47)^{*}\end{array}$ & 0.0001 & $\begin{array}{l}-7.9534 \\
(2.89)^{*}\end{array}$ & 0.0001 \\
\hline Minority & & & $\begin{array}{l}0.3002 \\
(1.69)\end{array}$ & 0.1107 \\
\hline African American & $\begin{array}{l}0.0257 \\
(0.28)\end{array}$ & 0.9137 & & \\
\hline Asian American & $\begin{array}{l}0.4491 \\
(1.75)\end{array}$ & 0.1039 & & \\
\hline Hispanic American & $\begin{array}{l}0.3641 \\
(1.52)\end{array}$ & 0.1323 & & \\
\hline Excess back-end ratio & $\begin{array}{c}-0.0592 \\
(4.58)^{*}\end{array}$ & 0.0001 & $\begin{array}{c}-0.0596 \\
(4.62)^{*}\end{array}$ & 0.0001 \\
\hline Excess LTV & $\begin{array}{c}-0.1748 \\
(2.06)^{*}\end{array}$ & 0.0388 & $\begin{array}{c}-0.1712 \\
(2.06)^{*}\end{array}$ & 0.0394 \\
\hline Credit score & $\begin{array}{l}0.0108 \\
(6.00)^{*}\end{array}$ & 0.0001 & $\begin{array}{c}0.0104 \\
(5.77)^{*}\end{array}$ & 0.0001 \\
\hline Prior bankruptcy indicator & $\begin{array}{c}-0.9772 \\
(1.93)\end{array}$ & 0.0527 & $\begin{array}{c}-1.0096 \\
(2.01)^{*}\end{array}$ & 0.0441 \\
\hline Prior charge-off indicator & $\begin{array}{c}-0.7891 \\
(2.94)^{*}\end{array}$ & 0.0032 & $\begin{array}{c}-0.7656 \\
(2.87)^{*}\end{array}$ & 0.0041 \\
\hline Self-employed indicator & $\begin{array}{c}-0.5964 \\
(2.02)^{*}\end{array}$ & 0.0431 & $\begin{array}{c}-0.5851 \\
(2.00)^{*}\end{array}$ & 0.0455 \\
\hline $\begin{array}{l}\text { Property value/loan amount } \\
\text { (Collateral) }\end{array}$ & $\begin{array}{l}0.9976 \\
(4.14)^{*}\end{array}$ & 0.0001 & $\begin{array}{c}0.9681 \\
(4.07)^{*}\end{array}$ & 0.0001 \\
\hline Number of observations & 567 & & 567 & \\
\hline $\begin{array}{l}\text { Hosmer-Lemeshow } \\
(p \text {-value })^{* *}\end{array}$ & 0.5587 & & 0.4970 & \\
\hline Log likelihood & -306.96 & & -307.92 & \\
\hline Pseudo R-square & 0.2161 & & 0.2186 & \\
\hline
\end{tabular}

Note: * Significant at the 5 per cent level, $t$-statistics are in parenthesis. ${ }^{*}$ There is no single, universally accepted measure of goodness-of-fit for logit regression comparable to R-square. Hence, HosmerLemeshow goodness-of-fit statistics (Hosmer \& Lemeshow, 1989) have been included to be the most intuitively appealing and the best suited to the probabilistic nature of the logit model. Although no absolute standard exists for this test statistics, higher $p$-values indicate better goodness-of-fit for a particular model specification. Two other goodness-of-fit measures are also reported and they are both consistent with the results indicates by the Hosmer-Lemeshow statistics.

banks can and should conduct independent and statistically rigorous fair-lending examination for the dual purpose of self-assessment and compliance with the federal fair-lending laws. Specifically, the study looked at 567 loan files from January to September 1999. The results indicate that the race variable, both when looked at collectively for all minorities and otherwise, is statistically insignificant. These findings are robust and have withstood a variety of stress tests. The finding also show that individual borrower's financial and creditworthiness are the real determinants of being denied or accepted for a home mortgage loan at this financial institution. Once again, it is believed that following the Bank-Specific Approach as outlined by Stengel \& Glennon (1999) is the major contribution of this study in the field of mortgage, minorities and discrimination. 
The point of this study is not so much whether discrimination exists or not, but how it may operate so that more effort can be made to eliminate it. In fact, the strong concern on the part of the regulators is its persistence despite several years of scrutiny, not whether it exists or not. In the past, some mortgage lenders have discriminated against some groups of borrowers and much of the discrimination was overtly part of their policy guidelines. As documented by Ladd (1982), mortgage lenders often discounted a wife's income by 50 per cent or more when evaluating mortgage application.

Even though these practices cannot be undone here, the question posed by Ladd (1998) can be addressed and answered: "now that racial discrimination in mortgage lending against minorities is clearly illegal under both ECOA and the FHA how plausible is it that banks still might continue to discriminate against protected groups, especially minorities?" The results of this study show that financial institutions are capable of conducting independent and statistically rigorous fair-lending exams, over and above the required regulatory procedures and policies, to evaluate the underwriting policy guidelines both for self-assessment and compliance with the federal fair-lending laws. This is the first step in addressing the problem of mortgage lending, minority applicants and discrimination.

Moreover, many mortgages are sold in the secondary market and a substantial fraction of mortgage lenders have little intention of keeping the loans they make. This added 'distance' in the transaction should reduce the likelihood of discrimination. As Day \& Liebowitz (1998), point out, "economic self-interests, therefore, should reduce racial discrimination in this market more completely than in many others" (p. 6).

\section{Acknowledgements}

The authors would like to thank Charles Connerly, Jason Dietrich, Tom Freeman, Jim Papadonis, Mitch Stengel and three anonymous referees for their valuable comments and suggestions. The views expressed in this paper are those of the authors and do not necessarily represent the views of FleetBoston Financial or Fannie Mae.

\section{Correspondence}

Sumit Agarwal, Fleet Boston Financial, Portfolio Risk Management, Mail Stop RI DE 03306A, 111 Westminster Street, Providence, RI 02903, USA. Email: Sumit_Agarwal@fleet.com.

\section{References}

Berkovec, J., Canner, G., Gabriel, S. \& Hannan, T. (1998) Discrimination, competition, and loan performance in FHA mortgage lending, Review of Economics and Statistics, 80, pp. 241-250.

Blackburn, M. \& Vermilyea, T. (2001) Racial discrimination in home purchase mortgage lending among large national banks. Economic and Policy Analysis Working Paper, Office of the Comptroller of the Currency.

Browne, L. E. \& Tootell, G. M. B. (1995) Mortgage lending in Boston-a response to the critics, New England Economic Review, September/October, p. 53.

Buist, H., Linnman, P. \& Megbolugbe, I. (1999) Residential-mortgage lending discrimination and lender-risk-compensation policies, Real Estate Economics, 27, pp. 695-717. 
Calem, P. S. \& Longhofer, S. D. (2002) (forthcoming) Anatomy of a fair-lending exam: the uses and limitations of statistics, Journal of Real Estate Finance and Economics.

Calomiris, C. W., Kahn, C. M. \& Longhofer, S. D. (1994) Housing finance intervention and private incentives: helping minorities and the poor, Journal of Money, Credit and Banking, 26, pp. 634-674.

Carr, J. H. \& Megbolugbe, I. F. (1993) The Federal Reserve Bank of Boston Study on mortgage lending revisited, Journal of Housing Research, 4, pp. 277-313.

Day, T. S. \& Liebowitz, S. J. (1998) Mortgage lending to minorities: where's the bias? Economic Inquiry, 36, pp. 3-28.

Dietrich, J. (2000) How low can you go? An optimal sample strategy for fair-lending exams. Economic and Policy Analysis Working Paper, Office of the Comptroller of the Currency.

Harrison, G. W. (1998) Mortgage lending in Boston: a reconsideration of the evidence, Economic Inquiry, 36, pp. 29-38.

Horne, D. (1994) Mortgage lending, race, and model specification, Journal of Financial Services Research, 11, pp. 43-68.

Hosmer, D. W. \& Lemeshow, S. (1989) Applied Logistic Regression (New York, John Wiley \& Sons).

Hunter, W. C. \& Walker, M. B. (1996) The cultural affinity hypothesis and mortgage lending decisions, Journal of Real Estate Finance and Economics, 13, pp. 57-70.

Ladd, H. F. (1982) Women and mortgage credit, American Economic Review, 72, pp. 166-170.

Ladd, H. F. (1998) Evidence on discrimination in mortgage lending, Journal of Economic Prospective, 12, pp. 41-62.

Maddala, G. S. (1983) Limited Dependent and Quantitative Variables in Econometrics (Cambridge, Cambridge University Press).

Munnell, A. G., Browne, L. E., McEneaney, J. \& Tootell, M. B. (1996) Mortgage lending in Boston: interpreting HMDA data, American Economic Review, 86, pp. 25-53.

Office of the Comptroller of the Currency (1997) Fair Lending-Comptroller's Handbook, October.

Rosenblatt, E. (1997) A reconsideration of discrimination in mortgage underwriting with data from a national mortgage bank, Journal of Financial Services Research, 11, pp. 109-131.

Ross, S. \& Yinger, J. (1999) Does discrimination in mortgage lending exist? The Boston Fed Study and its critics, in: M. Turner \& F. Skidmore (Eds) Mortgage Lending Discrimination: A Review of Existing Evidence (Washington, DC, The Urban Institute Press).

Scott, A. J. \& Wild, C. J. (1997) Fitting regression models to case-control data by maximum likelihood, Biometrika, 84, pp. 57-71.

Stengel, M. \& Glennon, D. (1999) Evaluating statistical models of mortgage lending discrimination: a bank-specific analysis, Real Estate Economics, 27, pp. 299-334.

Yezer, A. M. J., Phillips, R. F. \& Trost, R. P. (1994) Bias in estimates of discrimination and default in mortgage lending: the effects of simultaneity and self-selection, Journal of Real Estate Finance and Economics, 9, pp. 197-215.

Zandi, M. (1993) Boston Fed's Bias Study was deeply flawed, American Banker, 19 August. 